\title{
Exploring the relationship between educational mismatch, earnings and job satisfaction in the tourism industry
}

This article analyses the interrelationship between educational mismatch, wages and job satisfaction in the Spanish tourism sector in the first years of the global economic crisis. It is shown that there is a much higher incidence of overeducation among workers in the Spanish tourism sector than in the rest of the economy despite this sector recording lower educational levels. The study estimates two models to analyse the influence of the educational mismatch on wages and job satisfaction for workers in the tourism industry and for the Spanish economy as a whole. The first model shows that in the tourism sector the wage penalty associated with over-education is approximately $10 \%$. The second reveals that in the tourism sector the levels of satisfaction of over-educated workers are considerably lower than those corresponding to workers well assigned. With respect to the differences between tourism and the overall economy in both aspects, the wage penalty is substantially lower in the case of tourism industries and the effect of over-education on job satisfaction is very similar to that of the economy as a whole in a context where both wages and the private returns to education are considerably lower in the tourism sector.

Keywords: educational mismatch, job satisfaction, wages, over-education, crisis

\section{Introduction}

According to the OECD (2012) Spain is the member country of this organisation where the direct contribution of the tourism sector has the greatest relative weight in the overall economy in terms of gross added value $(10.2 \%)$ and employment $(11.5 \%)^{1}$. Moreover according to the World Tourism Organization (2013) in 2012 Spain ranked fourth in international tourist arrivals (57.7 million), and second (first in Europe) in

\footnotetext{
${ }^{1}$ The average contribution of tourism in OECD countries is $4.2 \%$ of GDP and $5.4 \%$ of employment (in the case of the European Union these figures are 4.4\% and 5.7\%, respectively) (OECD, 2012).
} 
international tourist receipts (US\$ 56 billion). The Spanish case is therefore a natural laboratory for the analysis of the tourism industry and the evidence obtained can be relevant for designing and monitoring tourism, education and labour policies adopted in other consolidated or growing tourism destinations.

It is well known that the characteristics usually attributed to employment in the sector are on the whole negative, as it is confirmed also in the Spanish case by the White Paper on Human Resources in Tourism (Exceltur, 2004): inconvenient working hours (including bank holidays, weekends, evenings and night shifts); greater number of working hours per week than in other sectors, uncompetitive wages, jobs that require few or no qualifications, low investment in training, low possibility for career development, low external recognition and social prestige, among other aspects. Tourism is traditionally one of the most labour intensive economic sectors and has resisted in a differentially positive way to the negative effects that the current financial and economic crisis are having on the Spanish labour market. This is confirmed by sources such as the Labour Force Survey (INE, several years) and particularly by the net data regarding Social Security Registration (Turespaña, several years), which for the period analysed in this article (2008-2010) reflect that 2009 was the only year in which the number of workers in the tourism sector affiliated to the Social Security scheme dropped (by 2.2\%), whereas in the economy as a whole, the fall began a year earlier with a particularly high figure in 2009 (a reduction of 5.7\%). This trend continued in 2010 for the overall economy, a year when the tourism sector experienced net increases in the number of Social Security registrations. Moreover, it is worth highlighting that a significant proportion of the workers in this sector are from the most disadvantaged groups of the labour market (women, young people, immigrants). On the other hand, not unrelated to this fact, this sector comprises a series of activities with low levels of 
labour productivity ${ }^{2}$ yet faces the same challenges as other economic sectors in a context of ever-increasing international competition, which requires the adoption of measures to improve its competitiveness through increasing productivity and quality and stimulating innovation.

According to the OECD (2012), given the relevance of the tourism sector in terms of its contribution to GDP and employment levels, it is natural for governments to focus on tourism as an area in which to develop and implement supporting programmes which could generate many benefits, including those related to education. To this respect, it is worth mentioning that different foresight exercises, including those carried out during the crisis, such as the afore-mentioned OECD project indicate that in the country members of this organisation there is an increasing risk of a lack of qualified labour and a need for employers to develop strategies to improve the attractiveness of the tourism industry and its capacity to retain workers. Among the different factors that could contribute to this trend, the OECD (2012) identifies the ageing of clients, changes in lifestyle and consumer demands, the increasing use of information and communication technology and globalisation which raises the demand for higher levels of skills even among the better-trained employees.

This article focuses on the analysis of the educational mismatch, and more specifically of the over-education in the Spanish tourism sector during the first phase of the economic crisis, and on its relationship with both the economic reward received by workers and their degree of job satisfaction, which are analysed by comparing the

\footnotetext{
${ }^{2}$ This is notably the case of the sub-sector of bars and restaurants, that concentrates a large share of tourism employment, although in other cases such as transport via railways and air transport the productivity is relatively high (Blake et al., 2006; Instituto de Estudios Turísticos, 2013).
} 
tourism sector and the overall economy.

Over-education (when an individual has a higher level of education than required for the job position that he/she performs) is a phenomenon with potentially negative effects for the individual, for the companies in which these workers develop their labour activity and for the economy as a whole. As summarised by McGuinness (2006), from an individual point of view, over-educated workers receive lower private returns on their investment in education compared with those of workers whose qualifications match the jobs in which they are employed. From the point of view of the company, there are many evidences to indicate that over-education is associated with lower productivity, which is partially related to a higher propensity of the affected workers to leave their jobs and to their lower levels of job satisfaction ${ }^{3}$.. From a global point of view, the national wellbeing will be lower than its potential level if the skills and knowledge of the workers are not fully utilised in the positions in which they are employed, and over-education would be associated with an inefficient use of the public resources which have been spent on this training. Finally, according to McGuinness (2006), there is a potential risk that the phenomenon feeds back on itself, whereby overeducated workers remove other workers from jobs for which they are appropriately trained, who, in turn generate a similar effect on those who occupy positions with lower requirements, provoking the definitive exclusion of certain lower-educated groups from the labour market.

As indicated above, this article examines the possible existence of over-

\footnotetext{
${ }^{3}$ This evidence has been however challenged recently by Kampelmann and Rycx (2012), whose results based on the analysis of linked employed-employee panel data for Belgium suggest that additional years of over-education could indeed be beneficial for firm productivity due to the additional skills and capabilities acquired through schooling.
} 
education in the Spanish tourism industry's labour market, and the effects of this phenomenon from an individual's point of view in terms of wages and the levels of job satisfaction of those workers affected. To this end, the following section presents the data drawn from the Survey of Quality of Life at Work (ECVT) which used to be carried out each year by the Ministry of Employment and Social Security, for the initial period of the economic crisis, 2008-2010. Furthermore, a preliminary descriptive analysis is made of the educational mismatch in the Spanish tourism sector. In the third section, the methodology applied is described and the fourth section presents and discusses the results obtained for the two fundamental areas addressed in the study: the effect of overeducation on wage returns and the job satisfaction of the workers in the Spanish tourism sector compared to those in the economy as a whole. In the first part of section four, an extended Mincerian wage equation is estimated, while in the second part different parameters of measuring job satisfaction in the sector are explored and their relationship with the educational mismatch is analysed through estimating an ordered probit model. Finally, in section five the principal conclusions are presented.

\section{Data and exploratory analysis of the educational mismatch in the Spanish}

\section{Tourism sector}

The data used in this article refer to wage earners between 16 and 64 years of age who report to have reached a level of education higher than primary education. The source is the Survey of Quality of Life at Work (ECVT) (Ministry of Employment and Social Security), from which a pool has been constructed for the crisis period 2008-2010 with a size of 16,270 and 1,847 individuals corresponding respectively to the total sample for the Spanish economy and the tourism sector sub-sample. The variable of interest for this study, the educational mismatch, is estimated through a direct subjective method (Groot \& Maassen van den Brink 2000), according to which the worker is classified as being 
over-educated or not depending on his/her response to the following question "Do you believe that the position in which you are employed is appropriate in accordance with your education?”, for which there are four possible answers: (a) It is appropriate (b) It is lower than my level of education, (c) It is above my level of education and (d) I would need to receive different training to what I have received. Depending on the response given, the workers are classified into four categories: "appropriately educated”, "overeducated", "under-educated" and "needs different training”. Although in the literature other methods for estimating the incidence of over-education are proposed, in practice the choice of one method or another basically depends on the characteristics of the statistical source used, given that none are exempt from criticism. It is worth noting that according to Leuven and Oosterbeek (2011:296) "the existing approaches to measure overschooling are very much data driven [...] It is unclear which method is to be preferred”. The meta-analysis conducted by McGuinness (2006) reaches the conclusion that both in estimating the incidence and in evaluating the effect of over-education on wages, the different approaches used give rise to broadly consistent evidence. This same conclusion is also reached by, for example, Verhaest \& Omey (2006), whose results are substantially robust in the relationships of interest for the four different alternative ways of measuring educational mismatch.

Table 1 presents a first approach to measuring the educational mismatch. The data show that over-education affects around $21 \%$ of Spanish workers; a figure which is almost five percentage points higher in the tourism sector. It is worth pointing out that this is a phenomenon which seems to be becoming more prevalent over time. Therefore, the figures obtained in Lillo-Bañuls (2009) using the same source for the period 19992002, reflect that over-education then affected $19 \%$ of workers employed in tourism services. In any event, this result is coherent with other analyses of the whole of the 
Spanish economy which has also reveals an increase in the incidence of this phenomenon when other analytical techniques are used (Aguilar \& García, 2008; Murillo et al, 2010). It is worth mentioning that the extension of over-education in the tourism sector is compatible, to some extent paradoxically, with average training levels which are lower than those for the Spanish economy as a whole. So, for example, according to the statistical source used in this article, University graduates had a weight of $14 \%$ in the tourism sector in the period 2008-2010, a percentage that represents half of that observed for all Spanish wage earners. Table 1 also shows that the rest of the educational mismatches considered (represented by the categories "Under-educated" and "Needs a different training") are less common, which has been frequently observed in the literature and which has led educational mismatch to being identified with overeducation.

[Table 1 near here]

Table 2 illustrates that, as expected, over-education is not homogeneously distributed among the different educational levels, but is more pronounced among the higher levels. The most extreme case is that of workers employed in tourism activities who have obtained higher levels of education where approximately half of the group is over-educated ${ }^{4}$. With respect to the relationship between this variable and age, a higher incidence is observed among the youngest workers, a phenomenon which is common in the analyses on over-education (Leuven \& Oosterbeek, 2011). This fact is particularly prominent among tourism sector workers, where the levels of over-education of the youngest age group are fourteen percentage points higher than the 45-64 year-old group,

\footnotetext{
${ }^{4}$ Marchante et al. (2003) estimate for a sample of hotel and catering workers (data referring to an own survey carried out in Andalusia) an over-education of 61.5\% when only University graduates employed in the sector are contemplated.
} 
when this difference in the case of the total sample is eight percentage points. This result could indicate that over-education is a phenomenon which is at least partially transitory, something that would be compatible with the career mobility model proposed by Sicherman \& Galor (1990), according to which initial over-education is part of a long-run strategy, although it may be simply be due to the lower age groups having a higher average level of education, given the merely descriptive nature of this preliminary analysis.

[Table 2 near here]

Over-education is related, logically, to an excess supply of qualified workers in relation to the demand for their services by companies in the sector. This is the explanation given by authors such as García-Montalvo \& Peiró (2009) for the recent behaviour observed in the Spanish economy. From a supply point of view this is a phenomenon which, in the case of tourism, could be accentuated by the considerable increase in the number of people studying tourism in Spanish universities. So, for example, between the academic years 1988/89 and 2008/2009 the number of students enrolled on Tourism Diploma courses multiplied by 2.5 in a context where the overall number of students enrolled in the first and second cycles reduced by 25\% (INE, 2010). However, and given that the presence of university students among those employed in the tourism sector is much lower than in the rest of the economy, it seems clear that the higher over-education observed is largely related to factors of demand; that is, to the incapacity of the sector to offer positions with a higher level of requirements in terms of qualifications compared to the rest of the economy, which could be generating some of the pernicious effects (individual and social) highlighted in the Introduction.

\section{Methodology and variables}

The empirical part of this study analyses the effect of the educational mismatch on 
wages and levels of job satisfaction declared by the individuals comparing the overall Spanish economy with the sample of workers in the Spanish tourism sector.

First, and in order to analyse the possible influence of the educational mismatch on wages, an extended Mincerian wage equation has been estimated where the dependent variable is the hourly wage, Wi in logarithmic form (so that the estimated coefficients can be interpreted in terms of rates of return). The regressors, as well as those traditionally considered in Mincerian wage equations (years of education, Educ , and the work experience of the workers - calculated from the year the worker effectively began working-, $\operatorname{Exp}_{i}$, and its square), also incorporate a series of variables that can be grouped as a vector of personal characteristics (Per, which include sex with men as the reference category,- and whether the worker is an immigrant or not), territorial characteristics ${ }^{5}$ (Place, measured through the regional unemployment rate) and job position (Job, which includes the type of contract with respect to its duration indefinite is the reference category-, type of working day - full-time is the reference category-, and firm size -defined in four intervals and where 0-9 employees is the reference category). Finally, the variable of interest for this study is included: educational mismatch, by considering four discrete variables which allow the measurement of the differences that result from a wage earner being defined as appropriately educated (category of reference), over-educated (Over), under-educated (Under) and if she/he needs different training (NDT).

${ }^{5}$ Since this specification includes variables related to both individual characteristics and regional characteristics we applied a correction for arbitrary intra-region correlation, which was implemented using the 'cluster option' in STATA. This option allows considering the fact that observations are clustered into regions, and that they may be correlated within them, but would be independent between regions. 
$\log _{i}=\beta_{o}+\beta_{1}$ Educ $_{i}+\beta_{2} \operatorname{Exp}_{i}+\beta_{3} \operatorname{Exp}_{i}^{2}+\alpha$ Per' $^{\prime}+\lambda$ Job $^{\prime}+\gamma$ Place $^{\prime}+\beta_{7}$ Over $+\beta_{8}$

Under $+\beta_{9} N D T+u_{i}$

Second, and in order to estimate the effect of educational mismatch on satisfaction, an ordered probit model is estimated in which a measurement of the latter dimension is the dependent variable (model [2]). It is common knowledge that job satisfaction is a subjective indicator of wellbeing which workers experience in performing their jobs. This is the interpretation of, for example, Van der Meer \& Wielers (2013) and Gamero (2005), who have extensively analysed this variable in the Spanish case. According to these authors, the majority of economic research on job satisfaction interprets the assessments of satisfaction as direct indicators of wellbeing which is measured individually and related with the determinants of the utility function of the job. Therefore, the job satisfaction that the individual declares is an ordinal indicator of the latent variable of unobserved subjective wellbeing in the job is considered. In this interpretation, this continuous variable would be "coded" by the worker when interviewed according to the different levels of satisfaction which take values of 0 to 10 , and would correspond to different levels of wellbeing so that the latent, continuous and unobserved variable would become a variable with discrete and ordered values that can be obtained from the statistical source used. To compute the net effect of over-education on job satisfaction the variables considered in this second model [2] include all of those previously described and, additionally, the hourly wage logarithm, following a strategy which is analogous to that of Verhaest \& Omey (2006) since also potential indirect effects must be accounted for: “over-educated workers are found to earn more than those who have just the required education for the job [and] job satisfaction depends positively on worker’s wages” (Kampelmann \& Rycx, 2012:921). 


\section{Results}

\subsection{Over-education and wages}

The wages earned by the workers in the Spanish tourism sector are, on average, lower than those of the economy as a whole. According to the statistical source used in this study, the figures are $€ 7.7 / \mathrm{h}$ and $€ 8.8 / \mathrm{h}$, respectively. The difference increases as the educational level of the individuals rises, which is consistent with the abundant literature on returns on education in the Spanish tourism sector, which has shown that these returns are lower than those of other parts of the economy (among the most recent contributions stand, for example, Campos-Soria et al 2011, García-Pozo et al 2012 and Lillo-Bañuls \& Casado-Díaz 2012). For illustrative purposes, the average wage of university-educated workers employed in tourism is $€ 9.1 / \mathrm{h}$, compared to $€ 11.35 / \mathrm{h}$ in the overall Spanish economy. Therefore, there is a larger difference (20.1\%) than that observed for total workers (13\%). Those workers with university studies who declare that they are over-educated earn substantially lower wages: $€ 7.5 / \mathrm{h}$ in tourism and $€ 8.9 / \mathrm{h}$ in the economy as a whole which implies that in the tourism sector the remuneration of over-educated university graduated workers is, in fact, lower than the average wage of the sector. In this case, however, the difference between tourism and the economy as a whole is lower (15.6\%).

Table 3 shows the results obtained in estimating model [1]. On the whole, the results obtained are coherent with the literature on wage determinants; so, for example, a penalty is observed for women, immigrants and temporary contracts; larger-sized firms are associated with higher wages and the regional unemployment rate has a moderating effect on wages (the higher the regional unemployment figures the lower the wages). The greatest differences between employees in the tourism sector and the total sample are observed in the coefficients typically analysed in studies on human 
capital and wages. Therefore, with respect to returns on education, Table 3 confirms the results of other analyses: these returns are 50\% lower in the tourism sector when compared with the economy as a whole. Experience is hardly remunerated in the tourism sector which is contrary to what is observed in the wider economy.

With regard to the variable of interest for this study, and as would be expected, the result of the coefficient associated with over-education has a negative sign and is significant in the samples analysed. However, the coefficients of the under-education variable are insignificant, and the needs different training variable is only significant for the total sample. The results show, therefore, that over-educated workers earn lower wages than those who have a similar level of education and experience and are employed in a position for which they are appropriately educated. In specific terms, the average expected value of the wage differences between an over-educated worker with respect to the reference category (appropriately educated) ${ }^{6}$ is a reduction of $17.47 \%$ and $9.63 \%$ for the total sample and tourism respectively. The sign of the variable is coherent with that obtained in the international literature (see, for example, McGuinness 2006, Verhaest \& Omey 2006, and Leuven \& Oosterbeek 2011). Also, in the estimates carried out for the overall Spanish economy based on very different techniques and statistical sources, a significant and negative effect of over-education on earnings is systematically observed. It is worth pointing out, however, that even in those studies which used similar definitions of this concept, the specific value estimated for the wage penalty is highly diverse. Taking some of the more recent studies by way of example, Aguilar \& García (2008) find a value of 4\%, Budría \& Moro-Egido (2007) estimate a percentage of 9\% while Hernández \& Serrano (2012) estimate a value of 25\%. On the other hand, it is noteworthy that the penalty suffered by those employed in tourism is lower than that

\footnotetext{
${ }^{6}$ According to Halvorsen and Palmquist (1980) calculated as $\left(\exp \beta_{2}-1\right) \times 100$.
} 
in the overall economy, although this occurs in a context where the wages of tourism workers are substantially lower than the average as are the returns on the years of education $^{7}$, and in a context where the incidence of over-education is higher compared to overall economy ${ }^{8}$.

[Table 3 near here]

\subsection{Over-education and job satisfaction}

The objective of this section is to provide a deeper insight into the relationship existing between job satisfaction and over-education, as the latter is a widespread phenomenon in the sector and, as discussed in the previous section, is related to penalties in monetary terms. An analysis will confirm whether the lower earnings of tourism workers are compensated by other characteristics of the job positions in which they are employed. Although the existing literature on the issue provides mixed results this seems not to be true for overall economy. Thus whilst Hersch (1991), Verhaest \& Omey (2009) and Tsang (1987) find that over-educated workers are less satisfied than their adequately educated colleagues in similar jobs other studies conclude that the relationship simply does not exist or is not statistically significant (e.g. Büchel 2002, and Verhaest \& Omey

${ }^{7}$ The Wald test confirmed the significance at $1 \%$ level of the difference between the estimations of the over-education parameter for Tourism and total sample $(F(1,16253)=91.76$; Prob $>F$ $=0.0000)$, and a similar conclusion is reached with regards to the education parameter $(\mathrm{F}(1$, 16253) = 1057.18; Prob $>$ F = 0.0000).

${ }^{8}$ One rather technical explanation for this could also be related with the way education mismatch is measured here, i.e. there is not a count of the years of over-education but a fictitious variable that reflects the existence of the phenomenon according to the worker's self-assessment with regards to his/her job's requirements. If the average years of overeducation among those being overeducated in the tourism sector are in fact lower than those of the comparable group of workers in overall economy then the lower wage penalty could simply reflect this fact. 
2006). Before proceeding with the estimate of the previously-described model [2], this section will begin with a short descriptive analysis of the levels of job satisfaction of the workers in the tourism sector compared to those of the overall economy.

The data supplied by the 2008-2010 pool of the ECVT, enables an analysis to be made relating to satisfaction in the current job and to different aspects referring to working conditions and the work environment measured on a scale of 0 to 10 where the lowest value indicates the lowest level of satisfaction. As Table 4 shows, these elements are significantly related to some of the most prominent aspects of internationally defined codes of good practice in relation to the management of human capital in the sector. This is the case, for example, of Fáilte Ireland (2005) where, based on an analysis of best practice both in Ireland and other countries, proposals were made regarding "flexibility, participation, performance management, recognition, reward, communication, learning \& development and empowerment” (quoted in Baum, 2007).

Table 4 shows the values corresponding to the mean and the standard deviation for workers in the tourism sector compared with the workers in the economy as a whole and the difference, in percentage terms, between the average values of satisfaction of both groups in relation to each of the dimensions analysed.

[Table 4 near here]

The results show, first, a coincidence in the pattern of scores given by all of the workers, both in the tourism sector and the overall economy. The worst-scoring aspects are satisfaction with wages, flexibility of hours, in-company training and the possibility of being promoted. With respect to the difference between the two groups, starting with the last three variables considered in Table 4, it is evident that levels of stress and particularly the monotony and physical effort associated with the jobs in the sector are higher than in the economy as a whole. As for the different dimensions of job 
satisfaction considered, it can be observed that the scores given by workers in the tourism sector are lower in all of them. The largest differences can be seen in satisfaction with the working day, rest time, holidays and leave, stability the possibility of promotion and most prominently, in-company training. This last aspect is highly prominent in some of the criticisms made of the sector which underline its low capacity to create value through improving the training of its workers. It is paradoxical, however, that the lower satisfaction of tourism workers in all of the indices considered, together with their lower wages only translates into a small difference with respect to the overall level of satisfaction with the current job and the activity developed in relation to total workers (less than two percentage points), and especially the high score (more than seven and a half points and with a very low standard deviation). Although it would be venturesome to formulate hypotheses to this respect, it is highly possible that this assessment is related to the widespread unemployment in the Spanish economy, especially during the period of severe economic crisis analysed, which could give rise to a very positive evaluation of having a job although when this is broken down into its different dimensions, negative opinions are given for many of them.

Table 5 introduces the dimension of over-education in the previous analysis and shows that both for the total sample and tourism activities (where there is a higher incidence of over-educated workers) the levels of satisfaction are notably lower among individuals who consider that their level of education is higher than required for the position in which they are employed. This difference is observed in all the dimensions of job satisfaction analysed (with a significance of $1 \%$-see the note of Table 5), and the highest values correspond to satisfaction with in-company training (where the score given by over-educated workers is almost $30 \%$ lower than that of appropriately educated workers), and satisfaction with the possibility of promotion and wage, aspects 
for which there are differences of around $20 \%$. There are no noteworthy differences between workers in tourism activities and the overall economy in these three variables. There are differences between these two groups, however, with respect to aspects related to the organisation of time and work. In the tourism industry, the differences in satisfaction between over-educated workers and appropriately educated workers are fairly high (around five percentage points in practically all cases) when considering the working day, the flexibility of hours, rest time and holidays and leave, because it is in these variables where there is a larger gap between over-educated tourism workers and their counterparts in the overall economy. However, the negative effect of overeducation on satisfaction seems lower in tourism activities than the rest of the economy regarding the participation in decision making and the evaluation of superiors. To conclude, it is worth highlighting that the greatest difference in Table 5 is found in the monotony-routine dimension, with a higher level among over-educated workers than those who are appropriately educated, although to a much lesser extent in tourism (22.13\% versus 9.83\%), which is largely due to the differences existing between the scores that appropriately educated workers give to this dimension of satisfaction in tourism and the overall economy, given that this is one of the aspects where the difference between the situation perceived by the over-educated workers in the tourism sector and those in the total sample is lower.

[Table 5 near here]

Table 6 shows the ordered probit estimation of model [2], where the dependent variable is satisfaction with current job (0-10 scale) and the regressors included are identical to those of model [1] except for the additional inclusion of hourly net earnings in logs. 
[Table 6 near here]

It can be observed that both wages and the working day (in this case with lower levels of significance) affect satisfaction, as would be expected, which is coherent with the standard utility function (this result is analogous to the one recently obtained for a very wide sample of European countries by Meer \& Wielers 2013).

Of the variables included in the educational mismatch, only the one corresponding to over-education ${ }^{9}$ is significant at $1 \%$ in both groups of workers (employed in the tourism sector and the total sample). The results show that the levels of satisfaction of over-educated individuals are significantly lower than those who are appropriately educated and have similar educational levels. This result is coherent with previous literature: for example, Verhaest \& Omey (2006) obtained a similar result which is robust for the four different measurements of over-education in their study (although the size of the effect varies from one to another). Table 6 shows that the penalty resulting from over-education on levels of satisfaction is fairly similar in the total sample and among those employed in the tourism industry, as opposed to the wage penalty derived from over-education (Table 3) - it should be noted that in this case the years of education are not significant for the total sample and only have a $5 \%$ significance for the sample corresponding to the tourism sector.

With respect to the rest of the variables, women recorded higher levels of satisfaction (a result also consistent with the literature), although in the case of tourism the effect is much lower and the variable only has a significance of $10 \%$. Those who have fixed-term contracts, on the other hand, have higher levels of satisfaction, the effect of regional unemployment is highly significant and positive in both cases, as

\footnotetext{
${ }^{9}$ In addition, needing different training has a very negative effect on levels of satisfaction.
} 
would be expected, and the size of the firm is also significant (with a negative effect on satisfaction -wage is included as a regressor) in the total sample, but not in the sample corresponding to tourism activities.

To conclude this section, it should be pointed out that the results obtained indicate the need to improve the assignment of job positions in relation to the educational levels of candidates. On the one hand, despite the average educational levels in the tourism sector being lower than those observed in the overall economy, the phenomenon of over-education is much more prevalent, especially at higher educational levels. The over-educated workers have returns on education that are substantially lower than those of workers with the same level of education who are considered to be correctly assigned to their job positions in these terms. On the other hand, the nonmonetary aspects of the working environment of over-educated workers do not seem to compensate this wage difference but, on the contrary, they accentuate it, given that their levels of satisfaction with the dimensions analysed are clearly lower than those of workers who consider themselves to be appropriately educated for the job in which they are employed. Although it seems reasonable that there is a certain level of educational mismatch (over-education) in entry-level positions in the early career stages, it seems that retaining workers in positions that are inferior to their educational level and with lower wages is not a good strategy for companies in the tourism sector. This has a negative effect on the motivation of workers and their satisfaction with the job they are performing is lower than other workers, which can have a negative impact on productivity and customer service in one of the sectors in which human capital has a higher relative relevance. 


\section{Conclusions}

The importance of the tourism sector in the Spanish economy in terms of GDP and employment is undeniable. Moreover the sector has been able to withstand some of the worst moments of the global financial and economic crisis better than others. However, it seems clear that there are large areas where greater value added and higher productivity levels could be achieved. This would lead to a better management and use of human capital in such a labour intensive sector in which workers have a significant role in the provision of services.

The estimates carried out in the article based on a sample drawn from the Survey of Quality of Life at Work (Ministry of Employment and Social Security) for the initial period of the global economic crisis have revealed that over-educated workers (workers whose level of education exceeds that required in order to perform the tasks inherent in the position in which they are employed) suffer a wage penalty. While being lower in the tourism industry that the rest of the economy, this penalty is reinforced by levels of satisfaction which are also clearly lower, as shown by the estimates, and occurs in a context of average wages being much lower in the tourism sector. From a social point of view, it seems clear that over-education is a sign that production resources are not being assigned correctly and their use is, at least in part, idle with respect to the human capital of those individuals affected by it. This phenomenon could also be detrimental for workers with a lower level of education who are sometimes displaced by those with a higher level who may be led to accept jobs with lower educational requirements than they have. This, in turn, may be passed on to other levels. Over-education also affects the motivation of workers, derived from penalties in terms of wages and satisfaction. This has been addressed in the article and can negatively affect the productivity of this 
group of workers since higher educated workers could be less productive if the characteristics of the jobs that they perform do not match their training.

Some of the more recent studies carried out by different international bodies, such as the OECD, underline the need for governments to implement training and education programmes in a sector which has an important strategic weight in many member countries. Paradoxically, given the indicators observed in the Spanish case, one of the greatest threats identified in these studies is a potential shortage of workers and skills. The existence of such a widespread incidence of over-education as that identified in this article in the case of Spain, and its implications in terms of private returns on education, wage penalty and satisfaction, undeniably constitute a challenge and offer a wide scope of action for all of the agents involved.

The figures related to the percentage of tourism workers holding university degrees that are affected by overeducation are very significant to be ignored. They cast some doubts about whether such higher education participation should be kept or expanded or maybe a more sound government policy could attempt to re-orientate part of this demand for education towards other paths where higher levels of job relevant skills should be reinforced. The excess of supply of educated workers is however only one side of this coin. In a sector where average levels of education are much lower compared to the rest of the economy it is difficult to assign the bulk of the responsibility to the supply side of this relationship. The sector as a whole might be underutilising the human resources available, a behavior which as has been pointed out may be costly to both individuals (the level on which this article focus) and firms, and the economy in a broader sense. This is due to the employers being either unable or unwilling to alter their production processes to fully utilise and reward the skills of their overeducated workers, as pointed out by McGuinness (2006). The employers' attitude in this issue 
could be positively influenced by government policies, associations and other relevant stakeholders through the promotion of the study and adoption of good practice codes and other measures. This change could also be the result of endogenous decisions fostered by more research on the field. This relates to how overeducation affects firms' productivity in the sector, and to what extent it could be raised through the improvement of the situation of those who are currently overeducated, both in pecuniary and nonpecuniary terms. 
References:

Aguilar, M.I. \& García, D. (2008). Desajuste educativo y salarios en España. Estadística Española, 50 (168), 393-426.

Baum, T. (2007). Human resources in tourism: Still waiting for change. Tourism Management, 28, 1383-1399.

Blake, A., Sinclair, M.T. \& Campos Soria, J.A. (2006). Tourism productivity. Evidence form the United Kingdom. Annals of Tourism Research, 33(4), 1099-1120.

Budría, S. \& Moro-Egido, A. (2007). Overeducation and Wages in Europe: Evidence from Quantile Regression, Documento de Trabajo Serie Economía E2007/04. Sevilla: Centro de Estudios Andaluces.

Campos-Soria, J.A.; García Pozo, A. Sanchez Ollero, J.L. \& Benavides-Chicón, C.G. (2011). A comparative analysis on human capital and wage structure in the Spanish hospitality sector. Journal of Service Science and Management, 4, 458-468.

European Commission (2010). Communication from the Commission to the European Parliament, the Council, the European Economic and Social Committee and the Committee of the Regions - Europe, the world's No 1 tourist destination - a new political framework for tourism in Europe [COM(2010) 352 final].

Exceltur (2004). Libro Blanco de los Recursos Humanos en turismo. Madrid: Exceltur.

Fáilte Ireland's (2005). A human resource development strategy for Irish Tourism. Competing through People, 2005-2012. Dublin: Fáilte Ireland.

Gamero, C. (2005). Análisis macroeconómico de la satisfacción laboral. Madrid: Consejo Económico y Social.

García Montalvo, J. \& Peiró, J.M. (2009). Análisis de la sobrecualificación y la flexibilidad laboral. Valencia: Fundación Bancaja.

García Pozo, A.; Campos Soria, Ja.; Sanchez Ollero J.L. \& Marchante Lara, M. (2012). The regional wage gap in the Spanish hospitality sector based on a gender perspective. International Journal of Hospitality Management, 31, 266-275. 
Groot, W. \& Maassen Van Den Brink, H. (2000). Overeducation in the labor market: A meta-analysis. Economics of Education Review, 19(4), 149-158.

Halvorsen, R. \& Palmquist, R. (1980). The interpretation of dummy variables in semilogarithmic equations. American Economic Review, 70 (3), 474-475.

Hersch, J. (1991). Education mismatch and job mismatch. Review of Economics and Statistics, 73(1), 140-144.

INE (Instituto Nacional de Estadística) (2010). Estadística de la Enseñanza Universitaria en España. Curso 2008-2009. Madrid: Instituto Nacional de Estadística.

INE (Instituto Nacional de Estadística) (several years). Economically Active Population Survey (EAPS). Annual Measures. Available at http://www.ine.es/en/inebaseDYN/epa30308/epa_publi_en.htm

Instituto de Estudios Turísticos (2013). Balance del turismo. Año 2012. Madrid: Instituto de Estudios Turísticos.

Kampelmann, S. \& Rycx, F. (2012) The impact of educational mismatch on firm productivity: Evidence from linked panel data. Economics of Education Review, 31, 918-931.

Leuven, E. \& Oosterbeek, H. (2011). Overeducation and Mismatch in the Labor Market. Handbook of the Economics of Education, Vol. 4, 283-326.

Lillo-Bañuls, A. (2009). El papel del capital humano en el sector turístico: algunas reflexiones y propuestas. Cuadernos de Turismo, 24, 53-64.

Lillo-Bañuls, A. \& Casado-Díaz, Jm. (2012). Individual returns to education in Spanish tourism sector during the economic crisis. Tourism Economics, 18(6), 1229-1249

Marchante, A.; Ortega, B. \& Pagán, R. (2005). Educational mismatch and wages in the hospitality sector. Tourism Economics, 11(1), 103-117.

McGuinness, S. (2006). Overeducation in the labour market. Journal of Economic Surveys, 20(3), 387-418. 
Mincer, J. (1974). Schooling, Experience and Earnings. New York: NBER (reprinted in 1993 by Gregg Revivals, Aldershot, UK, and Brookfield, USA).

OCDE (2012). OECD Tourism Trends and Policies 2012.

Sicherman, N. \& Galor, O. (1990). A theory of career mobility. Journal of Political Economy, 98(1), 169-192.

Tsang, M. (1987). The impact of underutilization of education on productivity: A case study of the U.S. Bell companies. Economics of Education Review, (3), 239-24.

Turespaña (Instituto de Turismo de España) (several years). Social Security

Registration. Annual data. Available at http://www.iet.tourspain.es/en-

EN/estadisticas/otrasestadisticas/empleoturistico/afiliacionss/paginas/series.aspx

Van der Meer, P.H. \& Wielers, R. (2013). What makes workers happy? Applied Economics, 45, 357-368.

Verhaest, D. \& Omey, E. (2006). The impact of overeducation and its measurement. Social Indicators Research, 77, 419-448.

Verhaest, D. \& Omey, E. (2009). Objective over-education and worker well-being: A shadow price approach. Journal of Economic Psychology, 30(3), 469-481.

World Tourism Organization (2013). UNWTO Tourism Highlights. Madrid: UNWTO. 
Table 1. Educational mismatch (\%).

\begin{tabular}{lll}
\hline & $\begin{array}{l}\text { Overall } \\
\text { economy }\end{array}$ & Tourism \\
\hline Appropriately educated & 74.78 & 69.63 \\
Over-educated & 21.33 & 26.04 \\
Under-educated & 1.84 & 1.68 \\
Needs different training & 2.05 & 2.65 \\
\hline
\end{tabular}

Source: Quality of Life at Work Survey 2008-2010 (Ministry of Employment and Social Security). 
Table 2. Educational mismatch in tourism by level of education and age groups.

\begin{tabular}{|c|c|c|c|c|c|c|c|c|}
\hline & Overall ec & nomy & & & Tourism & & & \\
\hline $\begin{array}{l}\text { Level of } \\
\text { education: }\end{array}$ & Adequate & Over & Under & NDT & Adequate & Over & Under & NDT \\
\hline Secondary & $83 \%$ & $13 \%$ & $2 \%$ & $2 \%$ & $83 \%$ & $13 \%$ & $2 \%$ & $2 \%$ \\
\hline $\begin{array}{l}\text { Professional } \\
\text { training }\end{array}$ & $74 \%$ & $21 \%$ & $2 \%$ & $2 \%$ & $69 \%$ & $25 \%$ & $2 \%$ & $4 \%$ \\
\hline Baccalaureate & $70 \%$ & $26 \%$ & $2 \%$ & $2 \%$ & $64 \%$ & $33 \%$ & $2 \%$ & $1 \%$ \\
\hline University & $71 \%$ & $26 \%$ & $1 \%$ & $2 \%$ & $49 \%$ & $48 \%$ & $1 \%$ & $2 \%$ \\
\hline Age groups: & Adequate & Over & Under & NDT & Adequate & Over & Under & NDT \\
\hline 16 to 30 years & $69 \%$ & $26 \%$ & $2 \%$ & $3 \%$ & $60 \%$ & $35 \%$ & $2 \%$ & $3 \%$ \\
\hline 31 to 44 years & $74 \%$ & $22 \%$ & $2 \%$ & $2 \%$ & $71 \%$ & $25 \%$ & $2 \%$ & $2 \%$ \\
\hline 45 to 64 years & $79 \%$ & $18 \%$ & $2 \%$ & $1 \%$ & $76 \%$ & $21 \%$ & $1 \%$ & $2 \%$ \\
\hline
\end{tabular}

Note: Adequate stands for 'Appropriately educated'; Over stands for 'Over-educated'; Under stands for 'Under-educated', and NDT stands for 'Needs different training'.

Source: Survey of Quality of Life at Work (ECVT) 2008-2010 (Ministry of Employment and Social Security). 
Table 3. Over-education and salaries (dependent variable is hourly net earnings in logs),

2008-2010.

\begin{tabular}{|c|c|c|c|c|}
\hline & \multicolumn{2}{|c|}{ Overall economy } & \multicolumn{2}{|l|}{ Tourism } \\
\hline Years of education & $0.060^{*}$ & $(0.001)$ & $0.030 *$ & $(0.003)$ \\
\hline Experience & $0.123^{*}$ & $(0.001)$ & $0.009 *$ & $(0.003)$ \\
\hline Experience $^{2}$ & $-0.000 *$ & $(0.000)$ & $-0.000 * *$ & $(0.000)$ \\
\hline Woman & $-0.117 *$ & $(0.006)$ & $-0.150 *$ & $(0.018)$ \\
\hline Born in a foreign country & $-0.077 *$ & $(0.013)$ & $-0.041^{* * *}$ & $(0.024)$ \\
\hline Fixed-term contract & $-0.066^{*}$ & $(0.007)$ & $-0.072^{*}$ & $(0.021)$ \\
\hline Part-time contract & $0.172 *$ & (0.009) & $0.218^{*}$ & $(0.022)$ \\
\hline $\begin{array}{l}\text { Firm size: } 10-49 \\
\text { employees }\end{array}$ & $0.064^{*}$ & (0.011) & $0.090 *$ & (0.018) \\
\hline $\begin{array}{l}\text { Firm size: } 50-249 \\
\text { employees }\end{array}$ & $0.110^{*}$ & $(0.010)$ & $0.111^{*}$ & $(0.023)$ \\
\hline $\begin{array}{l}\text { Firm size: } 250 \text { or more } \\
\text { employees }\end{array}$ & $0.180^{*}$ & $(0.009)$ & $0.199 *$ & $(0.022)$ \\
\hline $\begin{array}{l}\text { Log regional } \\
\text { unemployment }\end{array}$ & $-0.074^{*}$ & (0.019) & $-0.095 *$ & $(0.035)$ \\
\hline Over-educated & $-0.161^{*}$ & (0.008) & $-0.092 *$ & $(0.023)$ \\
\hline Under-educated & 0.005 & $(0.027)$ & 0.013 & $(0.075)$ \\
\hline $\begin{array}{l}\text { In need of different } \\
\text { training }\end{array}$ & $-0.063^{*}$ & $(0.017)$ & -0.003 & $(0.057)$ \\
\hline Constant & $1.315^{*}$ & $(0.054)$ & $1.713^{*}$ & $(0.098)$ \\
\hline$R^{2}$ & 0.3288 & & 0.1743 & \\
\hline Observations & 16,270 & & 1,847 & \\
\hline
\end{tabular}

Note: Dependent variable is hourly net earnings in logs. Significance levels: $* 1 \%, * * 5 \%$, $* * * 10 \%$. Controls for the survey year were included. Robust standard errors are reported in parentheses. Standard errors adjusted for clustering on Log regional unemployment.

Source: Authors' own calculations based on data from the Survey of Quality of Life at Work (ECVT) 2008-2010 (Ministry of Employment and Social Security). 
Table 4. Perceptions of the tourism workers and total sample (0-10 scale, Mean and SD in brackets).

\begin{tabular}{lccccc}
\hline & \multicolumn{3}{l}{ Overall economy } & Tourism & Difference \\
\hline Satisfaction with: & \multicolumn{7}{l}{} & & & \\
\hline Current job & 7.33 & $(1.70)$ & 7.20 & $(1.76)$ & $-1.77 \%$ \\
Wage & 6.04 & $(2.28)$ & 5.85 & $(2.32)$ & $-3.15 \%$ \\
Working day & 7.18 & $(2.26)$ & 6.83 & $(2.43)$ & $-4.87 \%$ \\
Flexibility of hours & 6.20 & $(3.16)$ & 5.98 & $(3.22)$ & $-3.55 \%$ \\
Rest times & 6.69 & $(2.65)$ & 6.30 & $(2.86)$ & $-5.83 \%$ \\
Holidays and leave & 7.54 & $(2.28)$ & 7.16 & $(2.52)$ & $-5.04 \%$ \\
Stability & 7.44 & $(2.54)$ & 7.10 & $(2.58)$ & $-4.57 \%$ \\
Activity developed & 7.69 & $(2.14)$ & 7.60 & $(1.78)$ & $-1.17 \%$ \\
Health and safety & 7.33 & $(2.14)$ & 7.25 & $(2.18)$ & $-1.09 \%$ \\
In-company training & 5.80 & $(3.04)$ & 5.19 & $(3.28)$ & $-10.52 \%$ \\
Organisation of work & 6.93 & $(2.06)$ & 6.91 & $(2.12)$ & $-0.29 \%$ \\
Autonomy/Independence & 7.38 & $(2.10)$ & 7.20 & $(2.25)$ & $-2.44 \%$ \\
Level of participation in decisions & 6.66 & $(2.56)$ & 6.38 & $(2.73)$ & $-4.20 \%$ \\
Possibility of promotion & 5.14 & $(3.10)$ & 4.91 & $(3.16)$ & $-4.47 \%$ \\
Evaluation of superiors & 7.03 & $(2.17)$ & 6.98 & $(2.28)$ & $-0.71 \%$ \\
Personal development & 7.44 & $(1.92)$ & 7.30 & $(1.98)$ & $-1.88 \%$ \\
\hline Level of: & & & & & \\
\hline Stress & 5.81 & $(2.89)$ & 5.98 & $(2.94)$ & $2.93 \%$ \\
Monotony -routine & 4.94 & $(3.00)$ & 5.36 & $(3.09)$ & $8.50 \%$ \\
Physical effort & 4.37 & $(3.14)$ & 4.90 & $(3.11)$ & $12.13 \%$ \\
\hline
\end{tabular}

Source: Author's own calculations based on the Survey of Quality of Life at Work (ECVT) 2008-2010 (Ministry of Employment and Social Security) 
Table 5. Perceptions of appropriately educated workers and over-educated workers in the total sample and the tourism sector (0-10 scale, Mean and SD in brackets).

\begin{tabular}{|c|c|c|c|c|c|c|}
\hline & \multicolumn{3}{|c|}{ Overall economy } & \multicolumn{3}{|c|}{ Tourism } \\
\hline & Appr. & Over & Difference $^{\mathrm{a}}$ & Appr. & Over & Difference $^{\mathrm{a}}$ \\
\hline \multicolumn{7}{|l|}{ Satisfaction with: } \\
\hline Current job & $\begin{array}{l}7.56 \\
(1.56)\end{array}$ & $\begin{array}{l}6.57 \\
(1.86)\end{array}$ & $-13.10 \% *$ & $\begin{array}{l}7.48 \\
(1.60)\end{array}$ & $\begin{array}{l}6.44 \\
(1.89)\end{array}$ & $-13.90 \%{ }^{*}$ \\
\hline Wage & $\begin{array}{l}6.30 \\
(2.16)\end{array}$ & $\begin{array}{l}5.13 \\
(2.38)\end{array}$ & $-18.57 \% *$ & $\begin{array}{l}6.20 \\
(2.14)\end{array}$ & $\begin{array}{l}4.99 \\
(2.46)\end{array}$ & $-19.52 \% *$ \\
\hline Working day & $\begin{array}{l}7.30 \\
(2.15)\end{array}$ & $\begin{array}{l}6.76 \\
(2.52)\end{array}$ & $-7.40 \% *$ & $\begin{array}{l}7.07 \\
(2.29)\end{array}$ & $\begin{array}{l}6.18 \\
(2.64)\end{array}$ & $-12.59 \% *$ \\
\hline Flexibility of hours & $\begin{array}{l}6.37 \\
(3.08)\end{array}$ & $\begin{array}{l}5.60 \\
(3.32)\end{array}$ & $-12.09 \% *$ & $\begin{array}{l}6.29 \\
(3.09)\end{array}$ & $\begin{array}{l}5.12 \\
(3.31)\end{array}$ & $-18.60 \% *$ \\
\hline Rest time & $\begin{array}{l}6.85 \\
(2.54)\end{array}$ & $\begin{array}{l}6.17 \\
(2.86)\end{array}$ & $-9.93 \% *$ & $\begin{array}{l}6.56 \\
(2.76)\end{array}$ & $\begin{array}{l}5.56 \\
(2.97)\end{array}$ & $-15.24 \% *$ \\
\hline Holidays and leave & $\begin{array}{l}7.70 \\
(2.15)\end{array}$ & $\begin{array}{l}6.98 \\
(2.56)\end{array}$ & $-9.35 \% *$ & $\begin{array}{l}7.40 \\
(2.32)\end{array}$ & $\begin{array}{l}6.50 \\
(2.81)\end{array}$ & $-12.16 \% *$ \\
\hline Stability & $\begin{array}{l}7.64 \\
(2.37)\end{array}$ & $\begin{array}{l}6.75 \\
(2.90)\end{array}$ & $-11.65 \% *$ & $\begin{array}{l}7.33 \\
(2.43)\end{array}$ & $\begin{array}{l}6.47 \\
(2.86)\end{array}$ & $-11.73 \% *$ \\
\hline Activity developed & $\begin{array}{l}7.91 \\
(1.55)\end{array}$ & $\begin{array}{l}6.94 \\
(2.00)\end{array}$ & $-12.26 \% *$ & $\begin{array}{l}7.86 \\
(1.61)\end{array}$ & $\begin{array}{l}6.87 \\
(2.00)\end{array}$ & $-12.60 \% *$ \\
\hline Health and safety & $\begin{array}{l}7.48 \\
(2.05)\end{array}$ & $\begin{array}{l}6.88 \\
(2.30)\end{array}$ & $-8.02 \% *$ & $\begin{array}{l}7.44 \\
(2.08)\end{array}$ & $\begin{array}{l}6.72 \\
(2.33)\end{array}$ & $-9.68 \% *$ \\
\hline In-company training & $\begin{array}{l}6.18 \\
(2.90)\end{array}$ & $\begin{array}{l}4.51 \\
(3.14)\end{array}$ & $-27.02 \% *$ & $\begin{array}{l}5.65 \\
(3.18)\end{array}$ & $\begin{array}{l}4.05 \\
(3.21)\end{array}$ & $-28.32 \% *$ \\
\hline Organisation of work & $\begin{array}{l}7.15 \\
(1.94)\end{array}$ & $\begin{array}{l}6.25 \\
(2.27)\end{array}$ & $-12.59 \% *$ & $\begin{array}{l}7.19 \\
(1.98)\end{array}$ & $\begin{array}{l}6.24 \\
(2.33)\end{array}$ & $-13.21 \% *$ \\
\hline Autonomy/independence & $\begin{array}{l}7.56 \\
(1.96)\end{array}$ & $\begin{array}{l}6.72 \\
(2.36)\end{array}$ & $-11.11 \% *$ & $\begin{array}{l}7.43 \\
(2.12)\end{array}$ & $\begin{array}{l}6.60 \\
(2.44)\end{array}$ & $-11.17 \% *$ \\
\hline Level of participation in decision & $\begin{array}{l}6.95 \\
(2.38)\end{array}$ & $\begin{array}{l}5.66 \\
(2.84)\end{array}$ & $-18.56 \% *$ & $\begin{array}{l}6.66 \\
(2.60)\end{array}$ & $\begin{array}{l}5.64 \\
(2.87)\end{array}$ & $-15.32 \% *$ \\
\hline Possibility of promotion & $\begin{array}{l}5.42 \\
(3.06)\end{array}$ & $\begin{array}{l}4.20 \\
(3.06)\end{array}$ & $-22.51 \% *$ & $\begin{array}{l}5.18 \\
(3.15)\end{array}$ & $\begin{array}{l}4.16 \\
(3.07)\end{array}$ & $-19.69 \% *$ \\
\hline Evaluation of superiors & $\begin{array}{l}7.25 \\
(2.02)\end{array}$ & $\begin{array}{l}6.32 \\
(2.45)\end{array}$ & $-12.83 \% *$ & $\begin{array}{l}7.18 \\
(2.20)\end{array}$ & $\begin{array}{l}6.46 \\
(2.34)\end{array}$ & $-10.03 \% *$ \\
\hline Personal development & $\begin{array}{l}7.72 \\
(1.68)\end{array}$ & $\begin{array}{l}6.44 \\
(2.29)\end{array}$ & $-16.58 \% *$ & $\begin{array}{l}7.6 \\
(1.76)\end{array}$ & $\begin{array}{l}6.45 \\
(2.23)\end{array}$ & $-15.13 \% *$ \\
\hline \multicolumn{7}{|l|}{ Level of: } \\
\hline Stress & $\begin{array}{l}5.82 \\
(2.86)\end{array}$ & $\begin{array}{l}5.70 \\
(2.96)\end{array}$ & $-2.06 \% * * *$ & $\begin{array}{l}5.93 \\
(2.97)\end{array}$ & $\begin{array}{l}6.03 \\
(2.89)\end{array}$ & $1.69 \%$ \\
\hline Monotony -routine & $\begin{array}{l}4.7 \\
(2.99)\end{array}$ & $\begin{array}{l}5.74 \\
(2.90)\end{array}$ & $22.13 \% *$ & $\begin{array}{l}5.19 \\
(3.11)\end{array}$ & $\begin{array}{l}5.70 \\
(2.98)\end{array}$ & $9.83 \% *$ \\
\hline Physical effort & $\begin{array}{l}4.29 \\
(3.09)\end{array}$ & $\begin{array}{l}4.61 \\
(3.22)\end{array}$ & $7.46 \% *$ & $\begin{array}{l}4.74 \\
(3.10)\end{array}$ & $\begin{array}{l}5.2 \\
(3.07)\end{array}$ & $9.70 \% * *$ \\
\hline
\end{tabular}

Note: Appr. stands for 'appropriately educated' and Over stands for 'over-educated'

a The significance levels, $* 1 \%, * * 5 \%, * * * 10 \%$, refer to a two sample t test of the null hypothesis that the population mean of variable is the same for both categories within each sample, appropriately educated and overeducated. The test does not assume that populations have equal variance.

Source: Authors' own calculations based on data from the Survey of Quality of Life at Work (ECVT) 2008-2010 (Ministry of Employment and Social Security). 
Table 6. Ordered probit estimate of satisfaction among workers in the tourism sector.

\begin{tabular}{|c|c|c|c|c|}
\hline & Overall eco & my & Tourism & \\
\hline Years of education & 0.004 & $(0.004)$ & $0.024 * *$ & $(0.007)$ \\
\hline Experience & $-0.012 *$ & $(0.003)$ & $-0.146 * * *$ & $(0.007)$ \\
\hline Experience $^{2}$ & $0.000^{*}$ & $(0.000)$ & $0.000^{* *}$ & $(0.000)$ \\
\hline Woman & $0.130 *$ & $(0.022)$ & $0.097 * * *$ & $(0.057)$ \\
\hline Born in a foreign country & $0.127 *$ & $(0.029)$ & 0.089 & $(0.067)$ \\
\hline Fixed-term contract & $-0.103^{*}$ & $(0.020)$ & $-0.181^{*}$ & $(0.050)$ \\
\hline Part-time contract & $0.070 *$ & $(0.027)$ & $0.122 * * *$ & $(0.073)$ \\
\hline Firm size: 10-49 employees & $-0.114^{*}$ & $(0.025)$ & -0.065 & $(0.055)$ \\
\hline Firm size: 50-249 employees & $-0.125 *$ & $(0.033)$ & -0.062 & $(0.076)$ \\
\hline $\begin{array}{l}\text { Firm size: } 250 \text { or more } \\
\text { employees }\end{array}$ & $-0.111^{*}$ & $(0.024)$ & -0.049 & $(0.056)$ \\
\hline Log regional unemployment & $0.262 *$ & $(0.053)$ & $0.255^{* *}$ & $(0.115)$ \\
\hline Over-educated & $-0.590 *$ & $(0.024)$ & $-0.659 *$ & $(0.058)$ \\
\hline Under-educated & $-0.158 *$ & $(0.061)$ & 0.101 & $(0.149)$ \\
\hline In need of different training & $-0.414 *$ & $(0.062)$ & $-0.334 * * *$ & $(0.174)$ \\
\hline LN of hourly wages & $0.286 *$ & $(0.032)$ & $0.186^{* *}$ & $(0.080)$ \\
\hline Log likelihood & $-29,470.73$ & & $-3,440.76$ & \\
\hline PseudoR ${ }^{2}$ & 0.022 & & 0.025 & \\
\hline Observations & 16,270 & & 1,847 & \\
\hline
\end{tabular}

Note: Significance levels: *1\%, **5\%, ***10\%. Controls for the survey year are included. Robust standard errors are reported in parentheses. Standard errors adjusted for clustering on Log regional unemployment.

Source: Authors' own calculations based on data from the Survey of Quality of Life at Work (ECVT), 2008-2010 (Ministry of Employment and Social Security). 